\title{
Note on "Protein dynamics and the allosteric transitions of pentameric receptor channels" by Jean-Pierre Changeux
}

Published online: 15 January 2015

(C) International Union for Pure and Applied Biophysics (IUPAB) and Springer-Verlag Berlin Heidelberg 2015

This article is part of the Special Issue "The Role of Protein Dynamics in Allosteric Effects". It was erroneously published in a regular issue of Biophysical Reviews ahead of the compilation of the Special Issue. Please click on the DOI link below to access the article.

Biophysical Reviews (2014) 6:311-321

DOI 10.1007/s12551-014-0149-z

Review

Protein dynamics and the allosteric transitions of pentameric receptor channels

Jean-Pierre Changeux

Received: 25 August 2014 /Accepted: 13 November 2014 /

Published online: 29 November 2014 